\title{
A Simple and Inexpensive Method for Evaluating the Photovoltaic Potential: Its Validation in Buenos Aires and Antarctica
}

\author{
Marcelo D. Cabezas, ${ }^{1}$ Jorge A. Hawryluk, ${ }^{2,3}$ Juan I. Franco, ${ }^{1}$ and Héctor J. Fasoli ${ }^{3}$ \\ ${ }^{1}$ Departamento de Investigación y Desarrollo en Energías Renovables-Instituto de Investigaciones Científicas y Técnicas para la Defensa \\ (DIDER-CITEDEF), San Juan Bautista de La Salle 4397, Provincia de Buenos Aires, B1603ALO Villa Martelli, Argentina \\ ${ }^{2}$ Facultad de Ingeniería, Universidad Católica Argentina, Alicia Moreau de Justo 1500, C1107AAZ Ciudad de Buenos Aires, Argentina \\ ${ }^{3}$ Facultad del Ejército, EST, IESE, UNDEF, Avenida Cabildo 15, C1426AAA Ciudad de Buenos Aires, Argentina \\ Correspondence should be addressed to Héctor J. Fasoli; hfasoli@gmail.com
}

Received 20 March 2016; Revised 2 June 2016; Accepted 26 June 2016

Academic Editor: Santanu Bandyopadhyay

Copyright (C) 2016 Marcelo D. Cabezas et al. This is an open access article distributed under the Creative Commons Attribution License, which permits unrestricted use, distribution, and reproduction in any medium, provided the original work is properly cited.

\begin{abstract}
The use of renewable energies requires a precise and detailed quantification of the resource available. Because of the cost of solar stations or limited availability of skilled human resources, in most emerging countries, this assessment is made only on a few points scattered over large areas. We report here a simple and inexpensive method to evaluate the photovoltaic (PV) potential for a specific geographic region and a given PV capture technology. The system allows for a direct evaluation of the energy actually obtainable by scaling the measurement array of photovoltaic cells. The proposed measurement system can be installed as a stand-alone unit, or as part of a measurement network, connected to a more sophisticated central hub. The measurement station consists of said PV array (or similar PV array), a resistor, and a portable data logger. The system is calibrated with a device composed of a small array of PV cells, a resistor load bank, and two multimeters. Due to its low cost, this system can be replicated as many times as required with minimal investment. This would make it possible to evaluate the available photovoltaic potential of large regions with accurate and detailed data. Measurements carried out in Buenos Aires and in Antarctica confirm the consistency of the method.
\end{abstract}

\section{Introduction}

The use of renewable forms of energy is imperative, mainly in emerging countries with large tracts of land with low population density. Alstone et al. [1] call for innovative approaches to address the energy needs of more than 1 billion people; Pillai and Banerjee [2] make a critical study about the use of renewable energy in India, where the majority of this country's population does not have access to electricity; Erisman et al. [3] claim to put people at the centre of a radical reforming in the management of the global change. Lack of energy of many of the world's population was the key point in the 4th International Conference on Applied Energy [4] and the 22nd World Energy Congress [5]; Yan et al. insist on the subject in two detailed articles [6,7]. Ahuja [8] proposes five ways for 2 billion people to have access to electricity (i.e., "to turn on lights and drink clean water") and Meier [9] suggests innovative financing mechanisms for the PV development in emerging regions. In addition, Hauser et al. [10] make an interesting prospective study on the energy and environment situation for future generations through an "International Goods Game"; their results appear to have implications for policy interventions designed to sustain international public goods.

Systems connected to the network and distributed generation installations require knowing the energy actually available that for a given energy source obviously depends on the local potential and the type of technology used. In the case of photovoltaic (PV) solar energy, procedures to calculate the power response of PV modules and to evaluate their interaction with the primary source are being extensively studied $[1,11-13]$. 
The currently used systems for evaluation of the incident solar energy are based on pyranometers or sensors made of silicon crystal associated with electronic devices. With this piece of equipment it is possible to quantify the PV potential through calibration procedures. The sensor is chosen according to its rate of response and other requirements [14, 15]. The correct design, calibration, and use of these sophisticated equipment provide good information about the irradiance at a given location $[16,17]$. On the other hand, many papers aimed at improving the prediction of the performance of a PV energy capture system have been published [14, 18-23]. From an adequate analysis of direct solar measurements and the predicted response of the PV systems it is possible to calculate the energy obtainable for a given location $[24,25]$.

It is well-known that the response of PV modules is a function of irradiance (that influences mainly the current) and temperature (which produces voltage variations) [14, 18, 19].

In particular, the effect of temperature on the PV cell under operating conditions is very difficult to estimate on the basis of meteorological records or measurements made on the PV module in the laboratory; this is due to its dependence on many factors whose effects are difficult to quantify [26].

It has been reported that results from work stations installed in specific locations can be used as reference for other geographic places; obviously, corrections for different meteorological conditions must be done. In this way, a probable energy yield can be effectively calculated based on the reliability of the data obtained and the correct evaluation of the parameters used in the simulations. Zhang et al. reviewed the state-of-the-art technologies for evaluating the reliability of large-scale PV systems [27]; on the other hand, Arboit et al. assessed the solar potential of low-density urban environments [28, 29]. Salazar and Raichijk studied the assessment of cloud conditions for determining the characteristics of solar resource availability and proposed a way to predict the actual cloud status in high altitude sites [30]. Zegaoui et al. developed a generalized model in order to simulate PV cells behavior; this model was validated experimentally [31]. Quansah et al. presented an empirical model for estimating Global Solar Radiation (GSR) at the Ashanti Region of Ghana; they noticed the effect of using or not air temperature measurements in their calculations [32]. Osinowo et al. [33] made a similar study analysis of GSR in Nigeria, the same as Coulibaly and Ouedraogo made in Burkina Faso [34]. Recently, Chin et al. reviewed 70 important papers on PV models; they discussed the varying degree of trade-off between accuracy, speed, and technical convenience [35]. Salam et al. made a technological and state-of-the-art review about advantages and limitations of soft computing techniques for maximum power point tracking of PV systems [36]. Their work completed the excellent 2009 paper by Bakirci [37]. Salazar and coworkers proposed practical models to estimate solar irradiance under different sky conditions $[38,39]$. Prediction models of stand-alone PV systems were extended to storage devices such as lead-acid batteries [40].

Although the use of sophisticated equipment provides accurate and detailed information regarding all variables concerning solar radiation, in most emerging countries detailed measurements of the solar potential are made only on a few points scattered over large areas [41-44]. Unfortunately, due to the cost of solar stations, the limited availability of skilled human resources, and low research budgets, it is impossible to install a sufficient number of measuring devices for the large areas under study [45-47]. Thus, important information related to the effect of local factors such as landforms, cloudiness, or presence of aerosols is not considered [2830, 40].

For these reasons, in large and sparsely populated emerging countries, it would be important to measure the PV potential by means of instruments that are (1) cheap enough to be replicated in many places; (2) accurate and precise; (3) reproducible to obtain a detailed local PV evaluation; and (4) easy to install, calibrate, and use.

In this paper we propose a simple and inexpensive system to assess with great detail and good accuracy the solar PV potential in any point of a geographical region for a given PV technology. The proposed evaluation set can be installed as a stand-alone unit, or as part of a measurement network, connected to a more sophisticated commercial measurement unit working as a central hub. This new evaluation system allows projecting a PV plant by scaling up of the area of the measurement device, a main goal for our studies on PV applications in Antarctica.

The system is based on a PV module connected to a single discharge resistor; the voltage drop across this resistor is periodically measured and recorded by a data logger.

The appropriate resistor value is selected by means of a calibration device. This consists of a small array of PV cells, a resistor load bank, and two multimeters and allows obtaining the discharge curves of the PV module under different possible levels of power output (related to the incident irradiance).

Thus, a linear relationship can be established between the voltage drop across the selected resistor and the maximum power obtainable from the PV module. In this way it is possible to calculate the power and the energy delivered by a determined PV system in a given location; this is done by the periodic record of the voltage drop across the selected resistor. In order to avoid large deviations in the results (mainly due to temperature effects), it is advisable to make the calibration within ranges in the vicinity of the final measurement conditions.

The measurement device proposed here is intended to neither characterize a photovoltaic system nor record the weather conditions at a geographical point but to perform an in situ quantification of the photovoltaic potential obtainable from a given technology in a specific geographic location.

The device is especially useful for development countries, where the financial resources do not allow access to sophisticated equipment.

\section{Experimental}

Three commercial KS-3T 12 V Solartec polycrystalline silicon photovoltaic cell modules having a rated power of $3 \mathrm{~W}$ were used (module dimensions are $243 \mathrm{~mm} \times 176 \mathrm{~mm}$; standard reference parameters corresponding to a solar radiation 


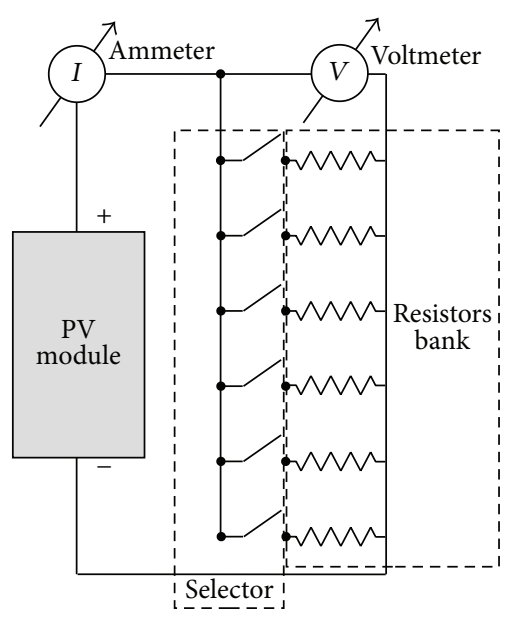

(a)

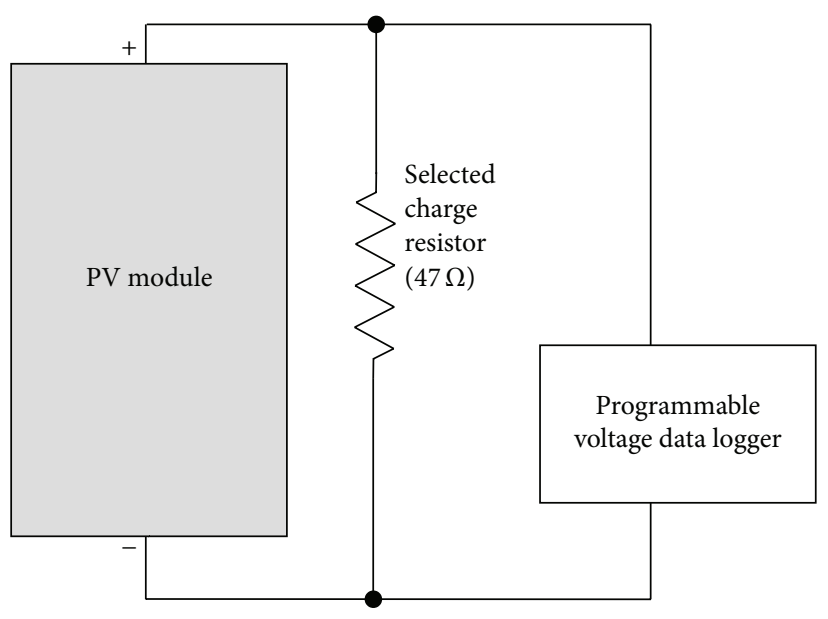

(b)

FIGURE 1: Calibration (a) and measurement (b) of circuit schemes.

intensity of $1 \mathrm{~kW} / \mathrm{m}^{2}$ and $25^{\circ} \mathrm{C}$ are rated voltage: $12 \mathrm{~V}$; shortcircuit current: $0.21 \mathrm{~A}$; and open-circuit voltage: $21 \mathrm{~V}$ ). Two Fluke 189 True RMS Multimeters were used for voltage and current measurements. The automatic data collection was performed using a Lascar Electronics EL-USB-3 0-30 V USB voltage data logger $0-30 \mathrm{~V}$. A resistor load bank constructed in our laboratory was used to obtain the $I-V$ response curves, which allow the characterization of the PV module; the resistance values ranged from 25 to $650 \Omega$. A diagram of the circuit used is shown in Figure 1(a). The calibration procedure was performed under irradiance levels greater than $1.10 \mathrm{~kW} \mathrm{~m}^{-2}$. From the set of $I-V$ curves obtained, the most appropriate resistance is chosen to build the measuring device (see diagram in Figure 1(b)); details of the procedure for this election are explained in the next section.

\section{Results and Discussion}

The resistive load bank was used to obtain the characteristic current-potential $(I-V)$ curves for the PV module to be used under different irradiance conditions (Figure 2). These results are consistent with the behavior of PV cells and PV modules extensively documented in the literature $[18,19]$. The curved zone for every $I-V$ function constitutes the working region in which the PV module delivers maximum power.

In Figure 3, the straight lines corresponding to the different resistance values for all calibration curves under different irradiance conditions are shown.

From those straight lines, it is necessary to choose the one with the lowest slope for which all points corresponding to the whole range of irradiance measurements are located within the evaluation area (low voltage area). As well-known, the current in this zone is a linear function of irradiance; therefore, the voltage across the terminals of the resistor is proportional to the irradiance and, in turn, the maximum power on the $I-V$ curve and the resistor voltage drop are linear functions of the irradiance (assuming constant temperature) $[14,19]$. Thus, for a given irradiance, it is possible to establish

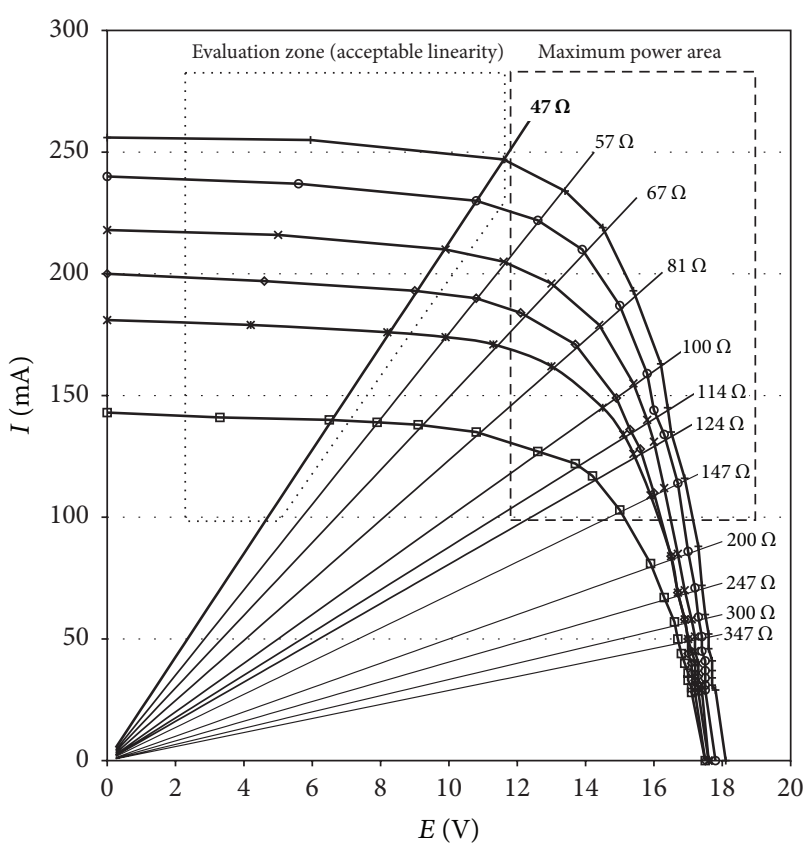

FIgURE 2: Load curves for one of the PV modules (calibration module) under different irradiance conditions. The dashed-line rectangle shows the area where maximum power is achieved. The area enclosed by the dotted lines is the evaluation zone in which acceptable linearity is observed for each characteristic $I-V$ curve.

a simple correspondence between the voltage measured for the selected resistance and the maximum power obtainable. It is also easy to see that, by using this straight line, the experimental errors are minimized.

In our case, the straight line chosen corresponds to $R=$ $47 \Omega$. For resistance values lesser than $47 \Omega$ the voltage values corresponding to two different irradiance conditions would be almost identical, making it difficult to distinguish between them (this is due to the high slope of the straight lines). 


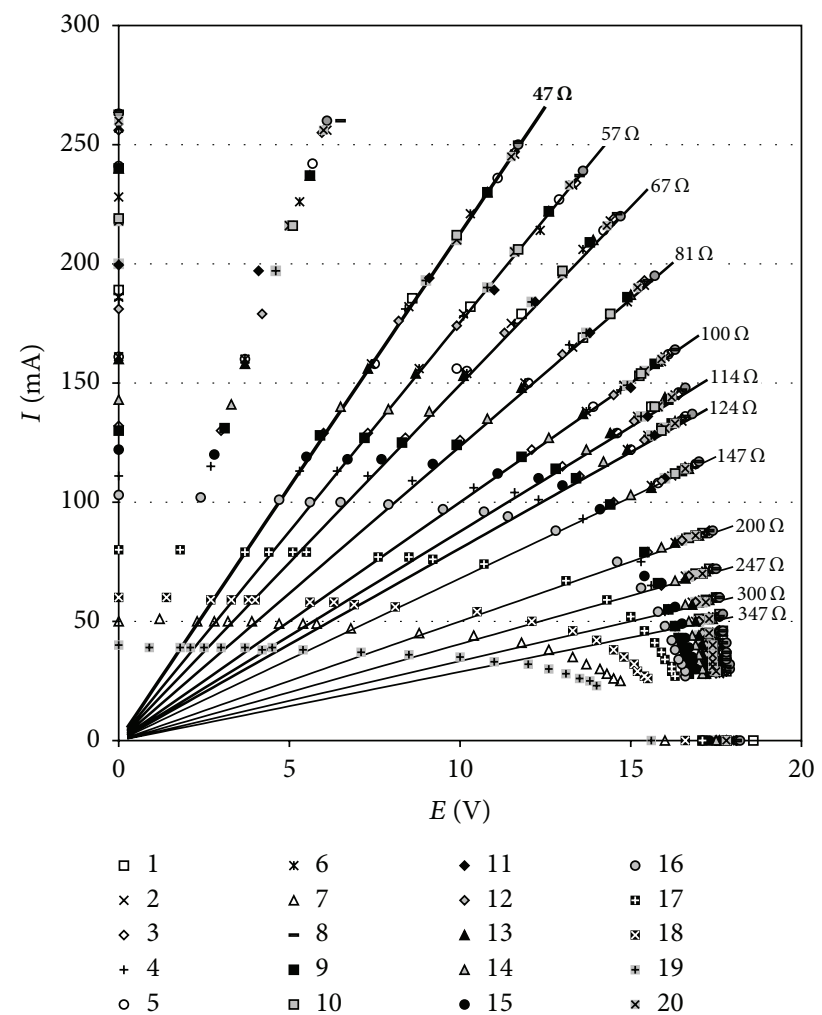

FIGURE 3: Complete set of load curves for calibration purposes (KS3T-12 V calibration module). The straight lines that correspond to the different resistance values for all calibration curves are shown.

In Figure 4 the power-voltage $(P-V)$ curves for different resistance values are shown. It can be seen that the curve $P=V^{2} / R$ for $R=47 \mathrm{ohms}$ is in the linear region for all loads. Because it has the lowest slope of all the load curves in the evaluation zone, it is easier to distinguish between two adjacent irradiance conditions.

Plotting the maximum power output $\left(P_{\max }\right)$ versus voltage for $R=47 \mathrm{ohm}\left(E_{47}\right)$ for each irradiance condition a linear relationship is obtained; the correlation factor is excellent (Table 1 and Figure 5).

In Table 1, only at point 19 a very high percentage deviation is observed. This could be because the measured power is very low. However it should be noted that in the calculation of the total energy (obtainable by integration of the registered powers) the influence of this measurement is minimized.

In order to verify the validity of the $P_{\max }-E_{47}$ linearity, measurements were performed under very different conditions for a calibration module and others similar to it (control module), as follows:

(i) Calibration module and control module under similar climatic conditions (Buenos Aires).

(ii) Control module under very different climatic condition (Esperanza Base, Antarctica).

Results are shown in Table 2 (see graph in Figure 6). It can be observed that, under similar climatic conditions,

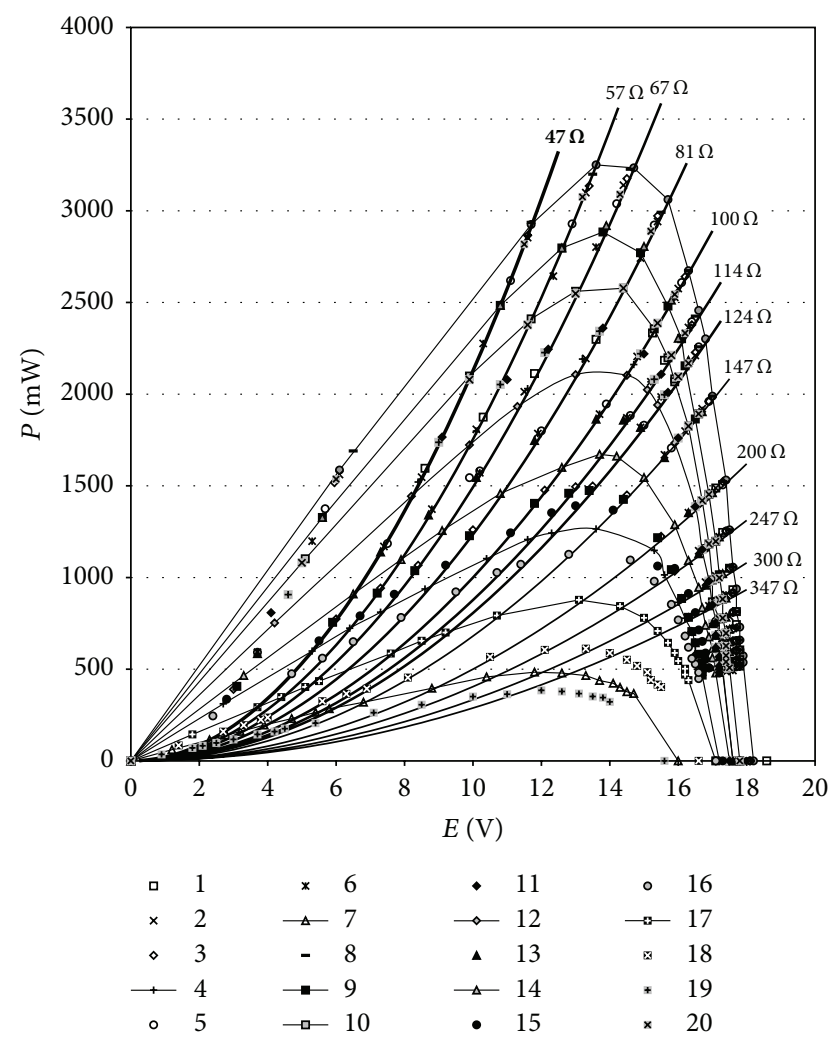

Figure 4: Power versus voltage curves obtained for the 20 load curves tested during calibration of the KS3T-12 V PV modules. The $47 \Omega$ load curve is entirely within the linear region of all calibration curves. Plotted from data of Figure 3.

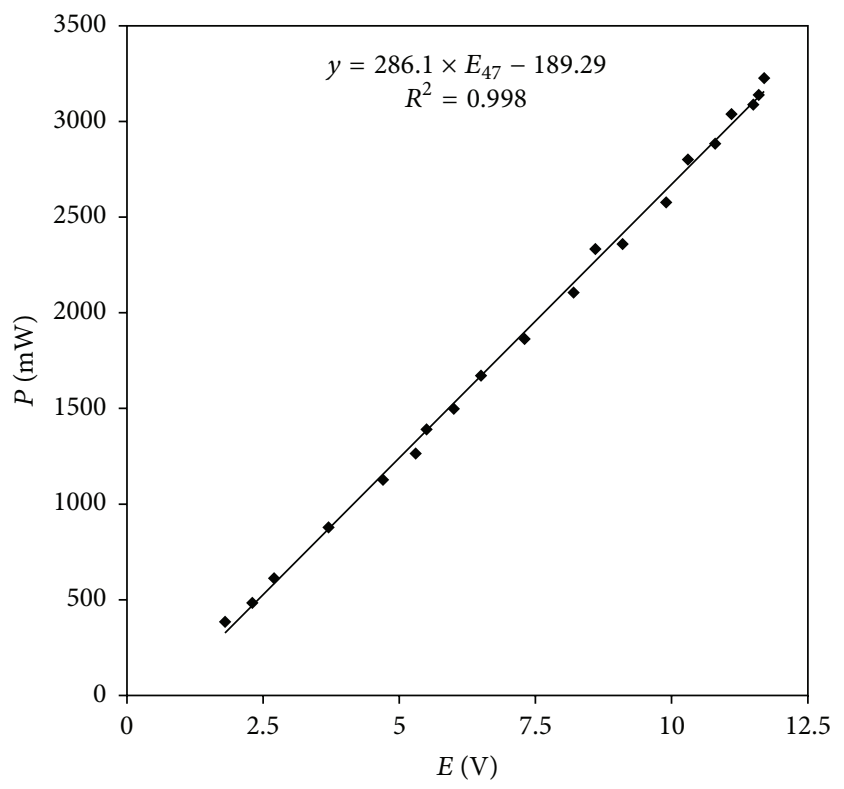

- Experimental maximum power $(\mathrm{mW})$

FIGURE 5: Graphical representation of experimental data from Table 1. Calculated linear regression is also shown.

deviations between the experimental and calculated values for the maximum power obtained for a given module are less 
TABLE 1: Experimental and calculated maximum power delivered by PV module. Percent deviations are also shown.

\begin{tabular}{|c|c|c|c|c|}
\hline \multirow{2}{*}{$N$} & \multirow{2}{*}{$E_{47}($ for $47 \Omega)(\mathrm{V})$} & \multirow{2}{*}{ Experimental maximum power $(\mathrm{mW})$} & \multicolumn{2}{|c|}{$286.1 \times E_{47}-189.29$} \\
\hline & & & Calculated maximum power $(\mathrm{mW})$ & Deviation (\%) \\
\hline 1 & 8.6 & 2333.3 & 2271.17 & -2.7 \\
\hline 2 & 11.6 & 3139.2 & 3129.47 & -0.3 \\
\hline 3 & 6 & 1498.5 & 1527.31 & 1.9 \\
\hline 4 & 5.3 & 1264.8 & 1327.04 & 4.9 \\
\hline 5 & 11.1 & 3038.8 & 2986.42 & -1.7 \\
\hline 6 & 10.3 & 2801.6 & 2757.54 & -1.6 \\
\hline 7 & 2.3 & 483.8 & 468.74 & -3.1 \\
\hline 8 & 11.7 & 3226.6 & 3158.08 & -2.1 \\
\hline 9 & 10.8 & 2884.2 & 2900.59 & 0.6 \\
\hline 10 & 9.9 & 2577.6 & 2643.10 & 2.5 \\
\hline 11 & 9.1 & 2359.8 & 2414.22 & 2.3 \\
\hline 12 & 8.2 & 2106.0 & 2156.73 & 2.4 \\
\hline 13 & 7.3 & 1863.2 & 1899.24 & 1.9 \\
\hline 14 & 6.5 & 1671.4 & 1670.36 & -0.1 \\
\hline 15 & 5.5 & 1391.0 & 1384.26 & -0.5 \\
\hline 16 & 4.7 & 1126.4 & 1155.38 & 2.6 \\
\hline 17 & 3.7 & 877.7 & 869.28 & -1.0 \\
\hline 18 & 2.7 & 611.8 & 583.18 & -4.7 \\
\hline 19 & 1.8 & 384.0 & 325.69 & -15.2 \\
\hline 20 & 11.5 & 3088.8 & 3100.86 & 0.4 \\
\hline
\end{tabular}

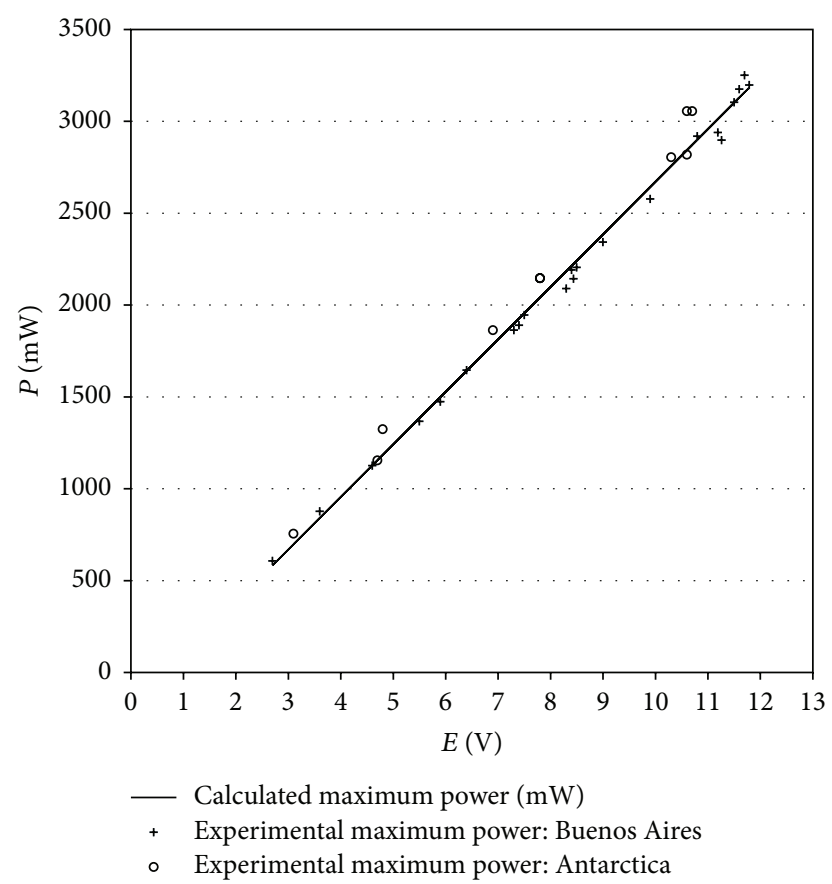

FIGURE 6: Experimental data compared to the calculated straight line.

than $5 \%$. Even for the experimental data taken with a different module, and under very different climatic conditions (Antarctica), the deviation of the calculated values remains less than $11 \%$. This increase in error is mainly attributable to the significant temperature difference between the location of

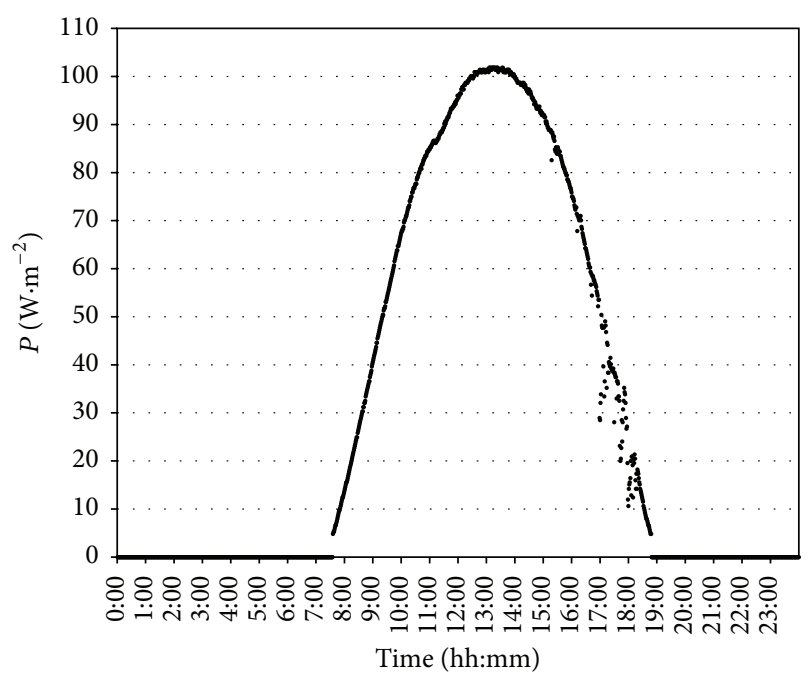

Figure 7: Calculated maximum power from the experimental data taken at Buenos Aires (one-day measurement; one data sam$\mathrm{ple} / \mathrm{min})$.

the measuring station and the location where the calibration was performed. However, the error remains within acceptable limits.

As an application example, the results for a sunny day in midsummer in Buenos Aires are shown. The voltages recorded by the data logger-one sample per minute [48, 49] - were used to calculate the power output during the period considered by applying the formula obtained previously (Figure 7). By integrating the power output over time, the total energy output is obtained. For the period considered, 
TABLE 2: Results obtained from measurements carried out under similar climatic conditions for the calibration and similar modules and measurements carried out under very different climatic conditions for a similar but not the calibration module.

\begin{tabular}{|c|c|c|c|c|c|}
\hline \multirow{2}{*}{$\begin{array}{l}\text { Register name: } \\
\text { Month/measure number/location }{ }^{* * *}\end{array}$} & \multirow{2}{*}{$\begin{array}{c}E_{47}(\text { for } 47 \Omega) \\
(\mathrm{V})\end{array}$} & \multirow{2}{*}{$\begin{array}{c}\text { Measured } \\
\text { maximum } \\
\text { power }(\mathrm{mW})\end{array}$} & \multicolumn{2}{|c|}{$286.1 \times E_{47}-189.29$} & \multirow{2}{*}{$\begin{array}{c}{ }^{* *} \text { Average temp. } \\
\left({ }^{\circ} \mathrm{C}\right) \\
\max / \min \\
\end{array}$} \\
\hline & & & $\begin{array}{l}\text { Calculated maximum power } \\
(\mathrm{mW})\end{array}$ & Dev. (\%) & \\
\hline $\mathrm{APR} / 1 / \mathrm{BA}$ & 8.5 & 2205.2 & 2242.6 & 1.7 & \multirow{18}{*}{$21.0 / 11.7$} \\
\hline $\mathrm{APR} / 2 / \mathrm{BA}$ & 8.4 & 2191.2 & 2214.0 & 1.0 & \\
\hline $\mathrm{APR} / 3 / \mathrm{BA}$ & 7.5 & 1946.0 & 1956.5 & 0.5 & \\
\hline $\mathrm{APR} / 4 / \mathrm{BA}$ & 7.4 & 1890.6 & 1927.9 & 2.0 & \\
\hline $\mathrm{APR} / 5 / \mathrm{BA}$ & 11.6 & 3175.5 & 3129.5 & -1.4 & \\
\hline $\mathrm{APR} / 6 / \mathrm{BA}$ & 5.9 & 1474.0 & 1498.7 & 1.7 & \\
\hline $\mathrm{APR} / 7 / \mathrm{BA}$ & 11.7 & 3250.4 & 3158.1 & -2.8 & \\
\hline $\mathrm{APR} / 8 / \mathrm{BA}$ & 10.8 & 2919.0 & 2900.6 & -0.6 & \\
\hline APR/9/BA & 9.9 & 2577.6 & 2643.1 & 2.5 & \\
\hline $\mathrm{APR} / 10 / \mathrm{BA}$ & 9.0 & 2342.7 & 2385.6 & 1.8 & \\
\hline APR/11/BA & 8.3 & 2089.8 & 2185.3 & 4.6 & \\
\hline $\mathrm{APR} / 12 / \mathrm{BA}$ & 7.3 & 1863.2 & 1899.2 & 1.9 & \\
\hline APR/13/BA & 6.4 & 1645.6 & 1641.8 & -0.2 & \\
\hline $\mathrm{APR} / 14 / \mathrm{BA}$ & 5.5 & 1367.7 & 1384.3 & 1.2 & \\
\hline APR/15/BA & 4.6 & 1126.4 & 1126.8 & 0.0 & \\
\hline APR/16/BA & 3.6 & 877.7 & 840.7 & -4.2 & \\
\hline APR/17/BA & 2.7 & 607.2 & 583.2 & -4.0 & \\
\hline APR/18/BA & 11.5 & 3103.1 & 3100.9 & -0.1 & \\
\hline JAN/1/BA & 11.3 & 2898.0 & 3032.2 & 4.6 & \multirow{4}{*}{ 29.8/19.6 } \\
\hline $\mathrm{JAN} / 2 / \mathrm{BA}$ & 8.4 & 2143.5 & 2225.4 & 3.8 & \\
\hline JAN/3/BA* & 11.2 & 2939.4 & 3012.2 & 2.5 & \\
\hline JAN/4/BA* & 11.8 & 3197.3 & 3183.8 & -0.4 & \\
\hline JAN/1/AN* & 10.6 & 3056.0 & 2843.4 & -7.0 & \multirow{10}{*}{$2.3 /-2.3$} \\
\hline $\mathrm{JAN} / 2 / \mathrm{AN}^{*}$ & 10.7 & 3056.0 & 2872.0 & -6.0 & \\
\hline $\mathrm{JAN} / 3 / \mathrm{AN}^{*}$ & 6.9 & 1863.0 & 1784.8 & -4.2 & \\
\hline $\mathrm{JAN} / 4 / \mathrm{AN}^{*}$ & 7.8 & 2146.2 & 2042.3 & -4.8 & \\
\hline $\mathrm{JAN} / 5 / \mathrm{AN}^{*}$ & 4.8 & 1324.8 & 1184.0 & -10.6 & \\
\hline JAN/6/AN* & 4.7 & 1155.0 & 1155.4 & 0.0 & \\
\hline JAN/7/AN* & 7.8 & 2146.2 & 2042.3 & -4.8 & \\
\hline $\mathrm{JAN} / 8 / \mathrm{AN}^{*}$ & 10.3 & 2805.0 & 2757.5 & -1.7 & \\
\hline JAN/9/AN* & 10.6 & 2819.0 & 2843.4 & 0.9 & \\
\hline JAN/10/AN* & 3.1 & 756.0 & 697.6 & -7.7 & \\
\hline
\end{tabular}

${ }^{*}$ Data taken from PV module similar to the calibration module.

${ }^{* *}$ For reference, the average temperatures for the evaluation days.

*** APR: April, autumn in southern hemisphere.

JAN: January, summer in southern hemisphere.

BA: Buenos Aires; Lat.: 34.5 S and Long.: 58.5 W.

AN: Esperanza Bay, Antarctica; Lat.: 63.4 S and Long.: 57.0 W.

the maximum energy obtainable was $739 \mathrm{Wh} / \mathrm{m}^{2}$. By extending the period of integration, the total energy delivered by the PV modules for any period of interest can be determined.

\section{Conclusions}

The proposed method has proven to be a valuable, easy to use, and inexpensive tool for the evaluation of photovoltaic potential for a given technology and installation.
The method allows a detailed assessment of vast territories with minimal investment in infrastructure, equipment, and man-hours.

Although advisable, the calibration needs not be carried out in the same region to be evaluated. Obviously, climate conditions must be similar for both locations (as a matter of fact, the difference in average maximum temperature should not exceed $10^{\circ} \mathrm{C}$; in addition, wind speed should not be dramatically different). 
By appropriate characterization of different PV modules, results from a given technology could be extrapolated to other technologies.

This method does not intend to replace commercial solarimetric stations but allows additional or "satellite" evaluations to obtain a much more detailed map at a much lower cost.

\section{Competing Interests}

The authors declare that there are no competing interests regarding the publication of this paper.

\section{Acknowledgments}

The authors thank the Secretaría de Ciencia Tecnología y Producción (Argentine Ministry of Defense) for cofunding this work (PIDDEF \# 21/11). They also acknowledge Alejandro Frak and Ricardo Aiello for their help in data acquisition.

\section{References}

[1] P. Alstone, D. Gershenson, and D. M. Kammen, "Decentralized energy systems for clean electricity access," Nature Climate Change, vol. 5, no. 4, pp. 305-314, 2015.

[2] I. R. Pillai and R. Banerjee, "Renewable energy in India: status and potential," Energy, vol. 34, no. 8, pp. 970-980, 2009.

[3] J. W. I. Erisman, G. Brasseur, P. Ciais, N. van Eekeren, and T. L. Theis, "Global change: put people at the centre of global risk management," Nature, vol. 519, no. 7542, pp. 151-153, 2015.

[4] J. Yan, S. K. Chou, U. Desideri, S. T. Tu, and H. G. Jin, "Research, development and innovations for sustainable future energy systems," Applied Energy, vol. 112, pp. 393-395, 2013.

[5] E. García Rodríguez, World Energy Insight 2013, World Energy Council, First, London, UK, 2013, http://www.worldenergy.org/ wp-content/uploads/2013/11/WEI2013.pdf.

[6] J. Yan, S. K. Chou, U. Desideri, and X. Xia, "Innovative and sustainable solutions of clean energy technologies and policies (Part I)," Applied Energy, vol. 130, pp. 447-449, 2014.

[7] J. Yan, S. K. Chou, U. Desideri, and X. Xia, "Innovative and sustainable solutions of clean energy technologies and policies (Part II)," Applied Energy, vol. 136, pp. 756-758, 2014.

[8] D. Ahuja, "People power," Nature, vol. 456, p. 25, 2008.

[9] T. Meier, Innovative Business Models and Financing Mechanisms for PV Deployment in Emerging Regions, IEA PVPS Task 9, Subtask 5 Report IEA-PVPS T9-14:2014, International Energy Agency-Photovoltaic Power System Programme (IEA PVPS), 2014, http://www.iea-pvps.org/index.php?id=311.

[10] O. P. Hauser, D. G. Rand, A. Peysakhovich, and M. A. Nowak, "Cooperating with the future," Nature, vol. 511, pp. 220-223, 2014.

[11] S. K. Gupta and R. S. Anand, "Development of solar electricity supply system in India: an overview," Journal of Solar Energy, vol. 2013, Article ID 632364, 10 pages, 2013.

[12] T. Nordmann, L. Clavadetscher, W. G. J. H. M. van Sark, and M. Green, "Analysis of long-term performance of PV systemsdifferent data resolution for different purposes. International Energy Agency-Photovoltaic Power System Programme (IEA PVPS) 2014. IEA PVPS task 13, subtask 1," Report IEA-PVPS T13-05, 2014, http://www.iea-pvps.org/index.php?id=305.
[13] G. K. Singh, "Solar power generation by PV (photovoltaic) technology: a review," Energy, vol. 53, pp. 1-13, 2013.

[14] K. Ishaque, Z. Salam, and H. Taheri, "Simple, fast and accurate two-diode model for photovoltaic modules," Solar Energy Materials and Solar Cells, vol. 95, no. 2, pp. 586-594, 2011.

[15] F. Vignola, "Solar cell based pyranometers: evaluation of the diffuse response," in Proceedings of the Annual Conference, American Solar Energy Society, vol. 260, 1999, http://solardat .uoregon.edu/download/Papers/SolarCellBasedPyranometers-EvaluationoftheDiffuseResponse.pdf.

[16] B. Parida, S. Iniyan, and R. Goic, "A review of solar photovoltaic technologies," Renewable and Sustainable Energy Reviews, vol. 15, no. 3, pp. 1625-1636, 2011.

[17] C. Morcillo-Herrera, F. Hernández-Sánchez, and M. FlotaBañuelos, "Practical method to estimate energy potential generated by photovoltaic cells: practice case at merida city," Energy Procedia, vol. 57, pp. 245-254, 2014.

[18] W. Zhou, H. Yang, and Z. Fang, "A novel model for photovoltaic array performance prediction," Applied Energy, vol. 84, no. 12, pp. 1187-1198, 2007.

[19] V. Lo Brano and G. Ciulla, "An efficient analytical approach for obtaining a five parameters model of photovoltaic modules using only reference data," Applied Energy, vol. 111, pp. 894-903, 2013.

[20] G. Kumar, M. B. Trivedi, and A. K. Panchal, "Innovative and precise MPP estimation using $\mathrm{P}-\mathrm{V}$ curve geometry for photovoltaics," Applied Energy, vol. 138, pp. 640-647, 2015.

[21] K. Emery, "Measurement and characterization of solar cells and modules," in Handbook of Photovoltaic Science and Engineering, A. Luque and S. Hegedus, Eds., chapter 16, pp. 701-752, John Wiley \& Sons, Chichester, UK, 2005.

[22] A. Dandoussou, M. Kamta, L. Bitjoka, P. Wira, and A. Kuitché, "Simulations based on experimental data of the behaviour of a monocrystalline silicon photovoltaic module," Journal of Solar Energy, vol. 2015, Article ID 169015, 9 pages, 2015.

[23] A. Bianchini, M. Gambuti, M. Pellegrini, and C. Saccani, "Performance analysis and economic assessment of different photovoltaic technologies based on experimental measurements," Renewable Energy, vol. 85, pp. 1-11, 2016.

[24] R. Mahtta, P. K. Joshi, and A. K. Jindal, "Solar power potential mapping in India using remote sensing inputs and environmental parameters," Renewable Energy, vol. 71, pp. 255-262, 2014.

[25] Y. Kashyap, A. Bansal, and A. K. Sao, "Spatial approach of artificial neural network for solar radiation forecasting: modeling issues," Journal of Solar Energy, vol. 2015, Article ID 410684, 13 pages, 2015.

[26] E. Skoplaki and J. A. Palyvos, "Operating temperature of photovoltaic modules: a survey of pertinent correlations," Renewable Energy, vol. 34, no. 1, pp. 23-29, 2009.

[27] P. Zhang, W. Li, S. Li, Y. Wang, and W. Xiao, "Reliability assessment of photovoltaic power systems: review of current status and future perspectives," Applied Energy, vol. 104, pp. 822-833, 2013.

[28] M. Arboit, A. Diblasi, J. C. Fernández Llano, and C. de Rosa, "Assessing the solar potential of low-density urban environments in Andean cities with desert climates: the case of the city of Mendoza, in Argentina," Renewable Energy, vol. 33, no. 8, pp. 1733-1748, 2008.

[29] M. Arboit, A. Mesa, A. Diblasi, J. C. Fernández Llano, and C. de Rosa, "Assessing the solar potential of low-density urban environments in Andean cities with desert climates: the case of 
the city of Mendoza, in Argentina. 2nd. Part," Renewable Energy, vol. 35, no. 7, pp. 1551-1558, 2010.

[30] G. Salazar and C. Raichijk, "Evaluation of clear-sky conditions in high altitude sites," Renewable Energy, vol. 64, pp. 197-202, 2014.

[31] A. Zegaoui, P. Petit, M. Aillerie et al., "Photovoltaic cell/panel/array characterizations and modeling considering both reverse and direct modes," Energy Procedia, vol. 6, pp. 695-703, 2011.

[32] E. Quansah, L. K. Amekudzi, K. Preko et al., "Empirical models for estimating global solar radiation over the Ashanti Region of Ghana," Journal of Solar Energy, vol. 2014, Article ID 897970, 6 pages, 2014.

[33] A. A. Osinowo, E. C. Okogbue, S. B. Ogungbenro, and O. Fashanu, "Analysis of global solar irradiance over climatic zones in Nigeria for solar energy applications," Journal of Solar Energy, vol. 2015, Article ID 819307, 9 pages, 2015.

[34] O. Coulibaly and A. Ouedraogo, "Correlation of global solar radiation of eight synoptic stations in Burkina Faso based on linear and multiple linear regression methods," Journal of Solar Energy, vol. 2016, Article ID 7870907, 9 pages, 2016.

[35] V. J. Chin, Z. Salam, and K. Ishaque, "Cell modelling and model parameters estimation techniques for photovoltaic simulator application: a review," Applied Energy, vol. 154, pp. 500-519, 2015.

[36] Z. Salam, J. Ahmed, and B. S. Merugu, "The application of soft computing methods for MPPT of PV system: a technological and status review," Applied Energy, vol. 107, pp. 135-148, 2013.

[37] K. Bakirci, "Models of solar radiation with hours of bright sunshine: a review," Renewable and Sustainable Energy Reviews, vol. 13, no. 9, pp. 2580-2588, 2009.

[38] G. A. Salazar, A. L. Hernández, and L. R. Saravia, "Practical models to estimate horizontal irradiance in clear sky conditions: preliminary results," Renewable Energy, vol. 35, no. 11, pp. 24522460, 2010.

[39] G. Salazar, P. Utrillas, A. Esteve, J. Martínez-Lozano, and M. Aristizabal, "Estimation of daily average values of the Ångström turbidity coefficient $\beta$ using a Corrected Yang Hybrid Model," Renewable Energy, vol. 51, pp. 182-188, 2013.

[40] R. Dufo-López, J. M. Lujano-Rojas, and J. L. Bernal-Agustín, "Comparison of different lead-acid battery lifetime prediction models for use in simulation of stand-alone photovoltaic systems," Applied Energy, vol. 115, pp. 242-253, 2014.

[41] G. Salazar, M. S. Checura Diaz, M. J. Denegri, and C. Tiba, "Identification of potential areas to achieve stable energy production using the SWERA database: a case study of northern Chile," Renewable Energy, vol. 77, no. 1, pp. 208-216, 2015.

[42] J. Almorox, M. Bocco, and E. Willington, "Estimation of daily global solar radiation from measured temperatures at Cañada de Luque, Córdoba, Argentina," Renewable Energy, vol. 60, pp. 382-387, 2013.

[43] R. Righini, H. Grossi Gallegos, and C. Raichijk, "Approach to drawing new global solar irradiation contour maps for Argentina," Renewable Energy, vol. 30, no. 8, pp. 1241-1255, 2005.

[44] M. Lave and J. Kleissl, "Solar variability of four sites across the state of Colorado," Renewable Energy, vol. 35, no. 12, pp. 28672873, 2010.

[45] M. S. Adaramola, "Estimating global solar radiation using common meteorological data in Akure, Nigeria," Renewable Energy, vol. 47, pp. 38-44, 2012.
[46] C. Tiba, N. Fraidenraich, H. Grossi Gallegos, and F. J. M. Lyra, "Solar energy resource assessment-Brazil," Renewable Energy, vol. 27, no. 3, pp. 383-400, 2002.

[47] C. Tiba, N. Fraidenraich, H. Grossi Gallegos, and F. J. M. Lyra, "Brazilian solar resource atlas CD-ROM," Renewable Energy, vol. 29, no. 6, pp. 991-1001, 2004.

[48] R. A. Gansler, S. A. Klein, and W. A. Beckman, "Investigation of minute solar radiation data," Solar Energy, vol. 55, no. 1, pp. 21-27, 1995.

[49] G. Vijayakumar, M. Kummert, S. A. Klein, and W. A. Beckman, "Analysis of short-term solar radiation data," Solar Energy, vol. 79, no. 5, pp. 495-504, 2005. 

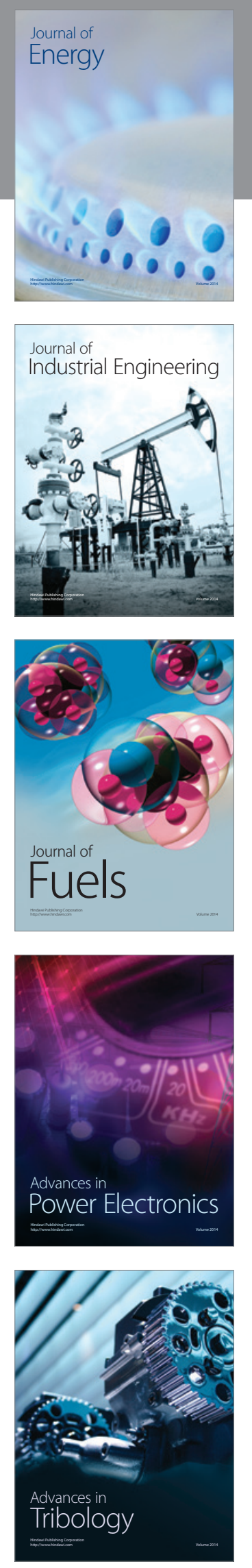
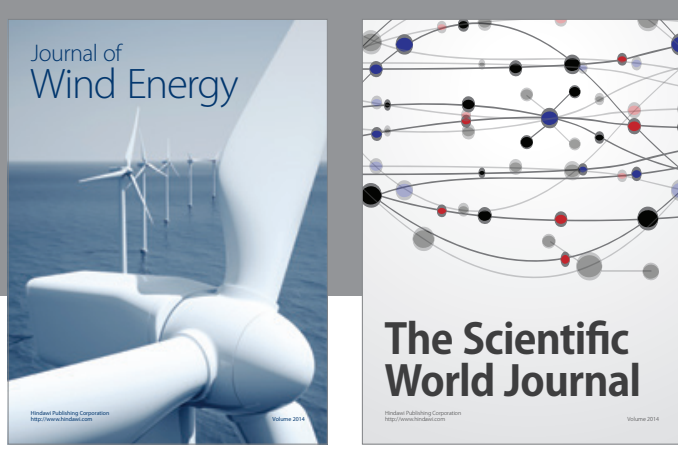

The Scientific World Journal
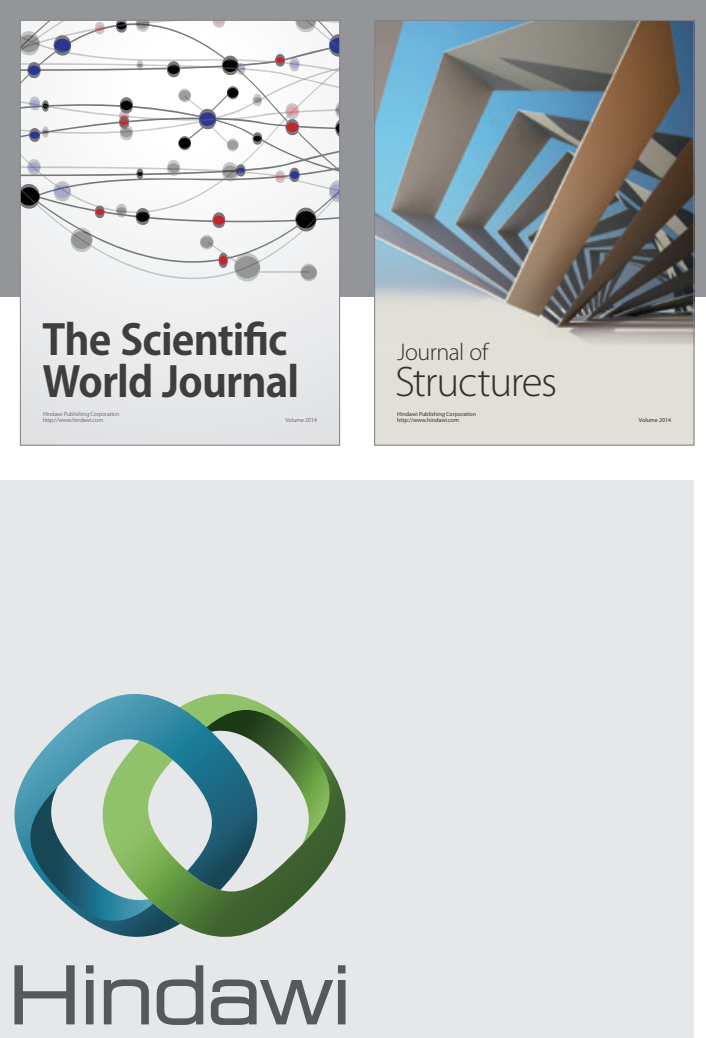

Submit your manuscripts at

http://www.hindawi.com
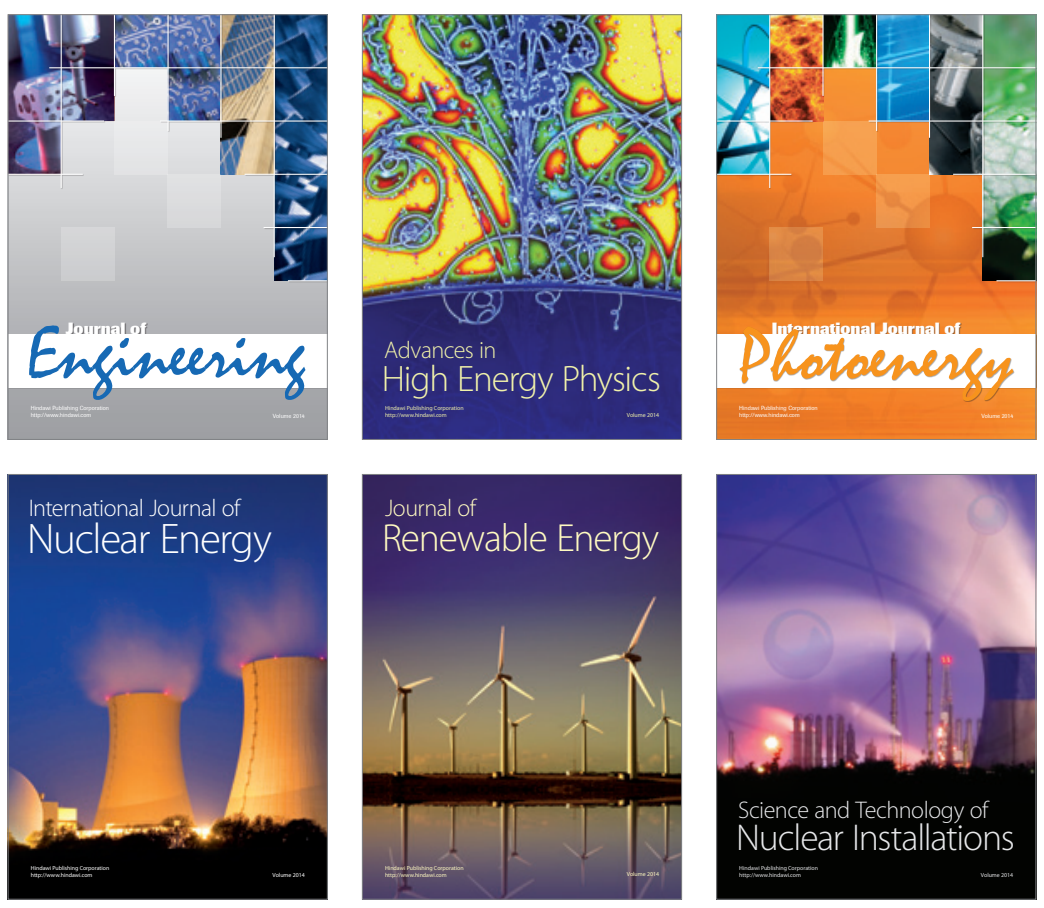
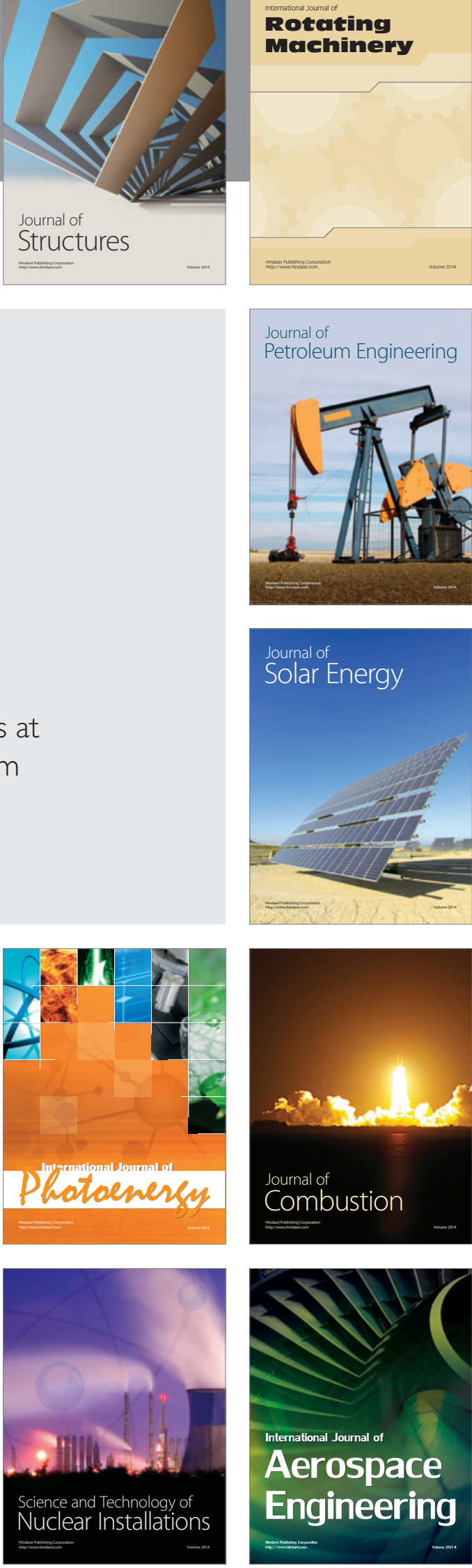